\title{
PEMIKIRAN ETIKA POLITIK MUHAMMAD CHOLIL BISRI DALAM AL-DURR AL-RUMBĀNĪ
}

\author{
Agus Irfan \\ agus.irfan@unissula.ac.id \\ Universitas Islam Sultan Agung Semarang \\ Sarjuni \\ alfahanin@gmail.com \\ Universitas Islam Sultan Agung Semarang
}

DOI: $10.21580 /$ wa.v7il.6547

\begin{abstract}
This article discusses the idea of Political Ethics from one of the Indonesian scholars named Muhammad Cholil Bisri in the Book of Al-Durr Al-Rumbanni. This study is under descriptive qualitative research using a socio-historical approach and sociology of knowledge that studies the interrelationships between thought and society. The results of this paper state that in Islam; the political problem is the area of ijtihādī which has strong roots in Islam. The relationship between them can be called a mutually reinforcing symbiotic relationship ('alāqah indimäjiyah). One of the influences of Islam in political traditions, for instance is its teachings on ethics that must inspire all policy issues. Even ethical configuration must also inspire the most important elements in the democratic political systems as called political parties. The term animates, explains that Islam as a system does not have to be realized in the form of formalization of sharia or political Islam movements. In addition to ethics, the goals that result from political dynamics must be in the form of benefit (maqșad al-siyāsah). Therefore, political work carried out in the corridor of truth can be considered as worship and deliver the politician to the noblest profession in the sight of God.
\end{abstract}

Keywords: Cholil Bisri, Political Ethics, Political Benefit, Political Party Reform

Abstrak 
$70 \mid$ Pemikiran Etika Politik ...

Artikel ini membahas tentang gagasan Etika Politik dari salah seorang ulama nusantara, Muhammad Cholil Bisri dalam Kitab Al-Durr Al-Rambānī. Kajian ini bersifat deskriptif kualitatif dengan menggunakan pendekatan sosio historis dan sosiologi pengetahuan yang mempelajari hubungan timbal balik antara pemikiran dan masyarakat. Hasil tulisan ini menyatakan bahwa dalam Islam, persoalan politik merupakan wilayah ijtihādī yang memiliki akar kuat dalam Islam. Hubungan keduanya dapat disebut sebagai hubungan simbiosis yang saling menguatkan ('alāqah indimäjiyah). Salah satu pengaruh Islam dalam tradisi politik misalnya, ajaran mengenai etika yang harus menjiwai seluruh aspek kebijakan. Bahkan konfigurasi etika juga harus menjiwai elemen terpenting dalam sistem politik demokrasi, yakni partai politik. Istilah menjiwai, menegaskan bahwa Islam sebagai sistem tidak harus diwujudkan dalam bentuk formalisasi sharī'ah atau gerakan Islam politik. Selain etika, tujuan yang dihasilkan dari dinamika politik harus berwujud kemaslahatan (maqsad alsiyāsah). Dengan demikian, kerja-kerja politik yang dilakukan dalam koridor kebenaran dapat dinilai sebagai ibadah dan mengantarkan politikus tersebut pada profesi yang paling mulia dalam pandangan Tuhan.

Kata Kunci: Cholil Bisri, Etika Politik, Politik Kemaslahatan, Reformasi Partai Politik

\section{A. Pendahuluan}

Kajian tentang pemikiran politik terutama yang berkaitan dengan etika dalam disiplin politik merupakan tema yang tergolong tua. Kehadirannya seiring dengan munculnya ilmu politik itu sendiri. Atau bahkan bebarengan dengan lahirnya manusia itu sendiri sebagai makhluk politik (zoon politican) yang tidak mungkin dihalangi untuk berpolitik. Dalam konteks kajian ini, persoalan yang akan dibahas seputar pemikiran etika politik yang lahir dari salah satu ulama sekaligus politikus Indonesia asal Rembang Jawa Tengah, Muhammad Cholil Bisri (1942 M - 2004 M). Pilihan itu didasarkan pada fakta bahwa Muhammad Cholil Bisri (selanjutnya Cholil Bisri) merupakan tokoh fenomenal yang dikenal khalayak sebagai figur ulama, politikus sekaligus seorang sosiolog.

Meskipun nama Cholil Bisri tidak semasyhur nama adik kandungnya, Ahmad Mustofa Bisri atau Gus Mus, namun sebagian masyarakat Indonesia terutama masyarakat Jawa dan kalangan santri tidak menyangsikan kepiawaiannya dalam memberikan ide-ide kebangsaan. Puncaknya Cholil Bisri menjadi salah satu anggota komite persiapan pembentukan partai baru pada 1998 selain Mustofa Bisri, Yusuf Muhammad, Abdullah Murtadha, Dawam Anwar, Abdul Aziz Mashuri dan Syaiful Bachri. ${ }^{1}$ Tugas komite ini adalah merumuskan segala sesuatu yang berkaitan dengan pembentukan partai baru dalam tempo 15 hari sebelum dikonsultasikan dengan Pengurus Besar Nahdlatul Ulama (PBNU). Proses

${ }^{1}$ Abu Asma et.al. Anshari, Ngetan Ngulon Ketemu Gus Mus: Refleksi 61 Tabun K.H.A. Mustofa Bisri (Semarang: HMT Foundation, 2005), 95. 
ini, membidani lahirnya Partai Kebangkitan Bangsa (PKB) pada 23 Juni 1998 dengan menempatkan Cholil Bisri sebagai Wakil Ketua Dewan Syuro DPP PKB.

Gagasan Cholil Bisri seputar etika politik menemukan relevansinya ketika dinamika politik di Indonesia akhir-akhir ini menunjukkan pergeseran makna politik menjadi reduktif, mulai dari perbincangan sampai pada isu yang digulirkan dan dipertentangkan. Reduksifikasi merupakan sebuah wujud dari proses pendangkalan dan menjadi antitesis dari saintifikasi sebagai proses aktivitas yang mengedepankan rasionalitas, keilmiahan dan kedalamannya. ${ }^{2}$ Dalam konteks kekinian, politik reduktif dapat dilihat dari fenomena Indonesia yang tengah menghadapi berbagai ujian kebangsaan yang tercermin dari lunturnya nasionalisme dan sikap bela negara, maraknya berita hoax dan penggunaan sentimen SARA dalam kehidupan sosial politik, serta maraknya kasus korupsi dan terorisme yang berimpit dengan gejala kemiskinan, pengangguran dan ketimpangan ekonomi. Semua ujian kebangsaan ini turut menguatkan adagium bahwa dunia politik memang dekat dengan kenaifan ${ }^{3}$ yang turut memudarkan sisi optimisme dalam kehidupan berbangsa.

Persoalan politik kebangsaan lainnya yang terjadi akhir-akhir ini adalah maraknya fenomena gerakan radikalisme agama yang berujung kepada gerakan sektarianisme dan terorisme. Gerakan yang dilakukan atas nama jihad ini tidak hanya menjadi primadona bagi kelompok "awam" yang skripturalis di dalam memahami teks, tapi gerakan antimainstream ini juga berhasil menyisir kelompok-kelompok "elit" dengan maraknya dunia kampus kenamaan menjadi bibit terorisme. ${ }^{4}$ Penelitian BNPT dalam tiga tahun terakhir mengungkapkan bahwa sebagian mahasiswa di Perguruan Tinggi Negeri di Jawa dan Sulawesi telah terpapar virus radikalisme baik dalam tahap pemikiran maupun sikap. Mereka menerima begitu saja paham dan dogma agama yang kaku, lalu mempraktikannya dalam diskusi-diskusi di organisasi mahasiswa. ${ }^{5}$ Temuan BNPT di atas, didukung oleh data terbaru dari Setara Institute yang di antara satu temuannya menyatakan bahwa di berbagai kampus negeri, wacana dan gerakan keagamaan eksklusif masih berkembang dan digencarkan oleh beberapa kelompok keislaman seperti gerakan Salafi-Wahabi, gerakan Tarbiyah dan gerakan

${ }^{2}$ E. Ermada Riyanto, Berfilsafat Politik (Yogyakarta: PT Kanisius, 2014), 14.

${ }^{3}$ Friedrich Nietzsche, On the Genealogy of Morality (USA: Cambridge University Press, 2007), 50-52.

${ }^{4}$ Penelitian MataAir \& Alvara Research Center pada 2017 yang melibatkan 1.800 mahasiswa di 25 PT unggulan dan 2.400 pelajar SMAN unggulan menyebutkan bahwa 23,5\% mahasiswa dan 16,3\% pelajar SMA setuju dengan jihad untuk tegaknya negara Islam atau khilafah. 18,6 \% mahasiswa dan 16,8 \% pelajar memilih ideologi Islam lebih tepat untuk Indonesia. 17,8 \% mahasiswa dan 18,3\% pelajar yang memilih Khilafah dibanding NKRI. 29,5\% mahasiswa dan 29,7\% pelajar menyatakan tidak akan mendukung pemimpin non muslim. Sementara penelitian lain MataAir \& Alvara Research Center pada 2017 yang melibatkan 1.200 Profesional PNS, BUMN, Swasta menunjukkan 29,7\% tidak mendukung pemimpin non muslim yang terpilih secara demokratis dan $27,6 \%$ mendukung perda syariah karena dianggap tepat untuk mengakomodir penganut agama mayoritas. Lihat https:/nasional.tempo.co/read/1029476/surveiberjihad\#fw4jtXi4Ue3WHXhM.41. Di akses pada 3 Juni 2018.

5 Tempo (28 Mei - 3 Juni 2018). 
$72 \mid$ Pemikiran Etika Politik...

Tahrīizyah yang berpotensi menjadi ancaman Pancasila, demokrasi dan keberlangsungan NKRI. ${ }^{6}$

Dengan menempatkan Islam lebih dari sekedar agama dan ideologi, maka corak kelompok ini selalu hitam putih di dalam melihat persoalan. Akibatnya akan ada selalu perdebatan mengenai Islam sebagai cara pandang (worldview) terkait isu-isu yang berkembang dan bersinggungan langsung dengan realitas sosial, terlebih persoalan ideologi politik yang terkadang mengharuskan keterlibatan seorang muslim untuk mendukungnya. Dalam konteks kebangsaan, kelompok radikal ini juga secara terang-terangan menyatakan penolakannya terhadap penyematan Pancasila sebagai dasar dan ideologi negara Indonesia. Mereka juga meyakini demokrasi tidak lebih dari sekedar sistem kafir dan menganggap perangkatnya sebagai kelompok țāghūt. ${ }^{7}$

\section{B. Konstruk Sosiologis Pemikiran Politik Cholil Bisri}

Cholil Bisri adalah anak sulung yang lahir pada Oktober 1941 dari pasangan Kiai Bisri Mustofa (selanjutnya Kiai Bisri) dan Ma'rufah binti Kiai Cholil Kasingan. Selain menempuh pendidikan di Sekolah Rakyat (1954), Cholil Bisri juga sekolah di Madrasah Ibtidāiyah (1954), kemudian melanjutkan di SMP Taman Siswa (1956) bersamaan dengan sekolah di Perguruan Islam (1956). Ia kemudian melanjutkan pendidikan ke Pondok Pesantren Lirboyo, Kediri, Jawa Timur, (1957), Pondok Pesantren al-Munawwir Krapyak, Yogyakarta (1960), Aliyah Darul Ulum Mekah (1962), dan IAIN Sunan Kalijaga Yogyakarta.

Cholil Bisri juga menjadi sosok penting di dalam menggagas dan membidani lahirnya Partai Kebangkitan Bangsa (PKB) sebagai wadah aspirasi politik warga NU. Bermula pada 6 Juni 1998, ia mengundang 20 kiai untuk membicarakan hal tersebut, dan tidak kurang 200 orang kiai datang. Dari pertemuan di rumahnya inilah gagasan tersebut mengkristal sampai proses pendirian PKB oleh Tim Kerja PBNU. Ketika PKB dideklarasikan pada 23 Juni 1998, Cholil Bisri masih menjadi salah satu tokoh penting. Ia menjadi Wakil Ketua Dewan Syuro DPP PKB, dengan Ketua Dewan Syuro Ma'ruf Amien dan Ketua Dewan Tanfdiziyah Matori Abdul Djalil. Keterlibatannya dalam PKB mengantarkannya menjadi anggota DPR dari PKB, bahkan sampai menjadi Wakil Ketua MPR. ${ }^{8}$

Tidak hanya menjadi sosok politisi, dalam diri Cholil Bisri juga terdapat sosok seorang kiai, penulis, dan sekaligus seorang sufi. Ia memegang tanggung jawab untuk menjadi pengasuh di Pesantren Raudhatut Thalibin dan tetap mengajar bandongan seperti Alfiyah, Sharah Fatḥ al-Mu'in, Jam'u al-Jawāmi', dan Ihyā' 'Ulümiddìn. Agaknya, kepribadian

${ }^{6}$ Lihat Ringkasan Eksekutif, "Wacana dan Gerakan Keagamaan di Kalangan Mahasiswa", Setara Institute (31 Mei 2019).

7 Agus Irfan, "Quo Vadis UU Ormas Dalam Dinamika Gerakan Islam Indonesia", dalam Annual Conference for Muslim Scholars, ed. M. Nuril Huda, et al. (Surabaya: Kopertais Wilayah IV, 2018), 213-214. Lihat juga, Agus Irfan, "Nalar Etika Politik A. Mustofa Bisri" (Disertasi-UIN Sunan Ampel, Surabaya, 2019), 182.

${ }^{8}$ Mengenal Almarhum KH. Cholil Bisri dalam https://www.nu.or.id/post/read/40566/mengenalalmarhum-kh-cholil-bisri. Diakses pada 14 Mei 2020. 
Cholil Bisri meneruskan trah keluarga besarnya sebagai kiai-kiai besar dan para penulis hebat termasuk pandangan etika politiknya yang tidak berbeda dengan pandangan politik ayahnya, Kiai Bisri Mustofa.

Dalam persoalan politik, Kiai Bisri berpandangan bahwa syariat Islam dapat terlaksana di Indonesia namun tanpa harus menggunakan formalisme agama dalam bentuk negara Islam (dār al-Islām). Kiai Bisri mendukung konsep Pancasila sebagai wawasan Nusantara, serta pilar NKRI. Ia mendorong komunikasi antara ulama dan zu'ama, yang bertujuan mencetak kader-kader handal di Nahdlatul Ulama. Pada konteks ini, Kiai Bisri berpandangan bahwa perjuangan bisa dilakukan dengan dua cara: yakni jalur politik dan jalur dakwah/pendidikan. ${ }^{9}$

Dalam bidang politik, Kiai Bisri pernah menjadi anggota konstituante. Perjuangannya dapat dilacak ketika beliau berkecimpung di parlemen maupun di luar struktur negara. Kiai Bisri juga dikenal sebagai sosok yang mendukung ide Soekarno, yakni konsep Nasakom (Nasionalis, Sosialis, Komunis). Kiai Bisri memberi catatan, bahwa ketika pihak yang berbeda ideologi, maka harus bersaing secara sehat dalam koridor keindonesiaan, dengan tetap mempertahankan NKRI. Akan tetapi, Kiai Bisri juga menjadi pengkritik paling tajam ketika Nasakom menjadi prahara politik. Diplomasi politik Kiai Bisri tidak hanya di ranah lokal, namun juga berpengaruh pada kebijakan politik nasional. Statusnya sebagai ulama tidak luntur dengan posisinya sebagai politisi dan jalan ini dilanjutkan oleh putranya, Cholil Bisri.

Meskipun menjadi politisi, keulamaan Cholil Bisri tidak ditangguhkan. Di Rembang, ia tetap mengajar ngaji dan menjadi pengasuh Pesantren Raudhatut Thalibin sampai ia meninggal dalam usia 62 tahun pada 23 Agustus 2004. Ia meninggalkan seorang istri bernama Muhsinah, delapan anak, dan sejumlah cucu. Di samping menjadi politisi, Cholil Bisri juga seorang penulis, bukunya yang telah diterbitkan adalah "Kami Bukan Kuda Tunggang" dan "Ketika Biru Langit". ${ }^{10}$ Sementara karya lain dalam bidang politik adalah AlDurr Al-Rumbānī, sebuah kitab Fiqh Siyāsah atau buku yang membahas politik dalam Islam yang memuat persoalan ideologi dan sistem politik kenegaraan dan termasuk di dalamnya banyak disinggung persoalan etika politik.

\section{Sekilas tentang Kitab Al-Durr Al-Rumbānī}

Kitab Al-Durr Al-Rumbānī karya Cholil Bisri ini, ditulis dengan menggunakan bahasa Arab, sebagai sebuah bahasa komunikasi yang lazim digunakan di dalam kultur pesantren baik aktif terlebih pasif. Kitab yang dicetak dan diterbitkan oleh Majelis dan Dewan Kehormatan Wilayah ini ditulis dengan tujuan untuk menambah referensi politik dalam Islam khususnya jika dihadapkan dengan tugas dan kewajiban ulama sebagai agen moral. Nilai lebih dari kitab ini terletak pada usaha Cholil Bisri yang tidak hanya

\footnotetext{
${ }^{9}$ Akhmad Zainul Huda, Mutiara dari Pesantren: Perjalanan Khidmah KH. Bisri Musthofa (Yogyakarta: LKIS. 2005), 108.

${ }^{10}$ Mengenal Almarhum KH. Cholil Bisri dalam https:/www.nu.or.id/post/read/40566/mengenalalmarhum-kh-cholil-bisri. Diakses pada 14 Mei 2020.
} 
$74 \mid$ Pemikiran Etika Politik...

menitikberatkan persoalan politik Islam pada isu-isu klasik, tetapi mengkontekstualisasikan dengan lokus kebangsaan dan keindonesiaan. Sebagaimana ditulis Cholil Bisri sendiri bahwa kemerdekaan Indonesia yang diproklamirkan oleh Soekarno dan Muhamad hatta bukanlah sebuah hadiah cuma-cuma namun kemerdekaan yang diperoleh dengan tetesan darah dan segala upaya yang telah dilakukan bangsa ini.

Karena itu, pasca kemerdekaan, rakyat Indonesia memiliki hak dan kewajiban yang sama untuk menghirup udara kebebasan di dalam negara demokrasi ini. Sebagai negara yang berdaulat, Indonesia mempunyai Undang-Undang yang mengatur kehidupan berbangsa dan kebebasan berserikat yang dikenal dengan Undang-Undang Dasar 1945 dengan rumusan pembukaannya yakni Pancasila. Sebagai dasar bernegara, baik Pancasila maupun UndangUndang Dasar tersebut berfungsi sebagai referensi di dalam merumuskan peraturan dan kebijakan yang maslahat. Dalam konteks kebangsaan, salah satu kebijakan yang maslahat adalah pemenuhan hak-hak warga negara secara elok dan adil dan di sinilah esensi politik kebangsaan yang menghubungkan antara kepemimpinan dan kerakyatan.

Deskripsi di atas merupakan potret dan pesan yang ingin disampaikan Cholil Bisri dalam kitab Al-Durr Al-Rumbānī tersebut. Di dalam menguraikan gagasannya, Cholil Bisri menulis setidaknya 12 pasal yang koheren satu pasal dengan pasal lainnya, meliputi: 1 . Pendahuluan, 2. Hakikat Politik, 3. Hubungan Politik dan Sharī'ah, 4. Antara Politik dan Jihad, 5. Politik dan Demokrasi, 6. Mushāwarah, 7. Partai Politik, 8. Hukum Kemasyarakatan, 9. Etika Politik, 10. Pembatasan Kedudukan Politik, 11. Hak dan Sistem Perwakilan, 12. Penutup.

Sebagai kitab Fiqh al-siyāsah yang mengurai persoalan politik dalam landscap Islam, pembahasan dalam pasal-pasal tersebut lebih bernuansa fiqh Sunni. Satu contoh misalnya keharusan adanya pemimpin disertai keharusan rakyat untuk taat dan tunduk kepada pemerintah, merupakan doktrin Sunni yang lazim dibahas dalam literatur klasik politik Sunni seperti Al-Aḥkàm al-Sulțānīyah karya al-Māwardī dan Al-Iqtị̦ād fì al'tiqād dan beberapa karya al-Ghazālī lainnya.

\section{Gagasan Etika Politik Cholil Bisri}

\section{Politik Maslahat}

Politik merupakan seni mengelola kepentingan warga. Politik yang beradab merupakan bentuk paling luhur dari sebuah bangsa yang berperadaban luhur. Mengutip pendapat al-Muqrīzī, Cholil Bisri menulis bahwa politik merupakan seni perundangundangan untuk menjaga peradaban, kemaslahatan dan keberaturan. Begitu juga pengertian yang ditulis Abu al Wafā ibn 'Aqīl bahwa politik merupakan kebijakan dan aktivitas yang mengantarkan kepada keadaban dan menjauhkan dari banalitas politik, meskipun tidak tersurat di dalam wahyu. ${ }^{11}$

Kemaslahatan pada jenis politik ini merupakan spektrum terpenting dalam politik yang dipacu oleh cinta dan kemanusiaan. Tanpa keduanya, Politik yang digelar hanya untuk

${ }^{11}$ Muhammad Cholil Bisri, Al-Durr al-Rumbānī (Jawa Tengah: MKW dan DKW PPP, t.t.), 6-7. 
kepentingan politik saja atau sekedar demokrasi prosedural yang melandaskan diri pada hak politik belaka yang abai terhadap nilai dan moralitas bangsa. Tegaknya keadilan disertai sikap toleransi dalam berbangsa merupakan esensi dan substansi tujuan politik (Maqāṣid alSharī'ah) sesungguhnya. Dalam hal ini Cholil Bisri menyebutkan bahwa :

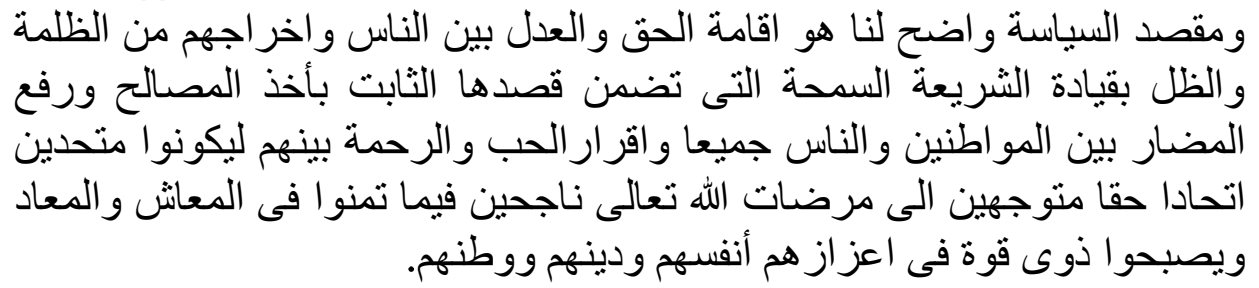

Tujuan politik sudah jelas yakni menegakkan kebenaran dan keadilan di antara manusia serta membebaskan mereka dari degradasi dan kedzaliman dengan menegakkan syariat yang toleran sebagai tujuan utamanya dengan mengambil maslahah dan menghilangkan bahaya (madiara $\bar{t}$ ). Tujuan lainnya adalah membangun budaya cinta dan kasih sayang di antara saudara sebangsa khususnya dan manusia pada umumnya yang didasarkan atas rị̄a Allah sehingga akan terbentuklah kesatuan dan kekuatan yang dapat mengantarkan kewibawaan mereka baik agama maupun bangsanya. ${ }^{12}$

Catatan Muhammad Cholil Bisri di atas, merupakan estapet dari pendapat mayoritas ulama yang menekankan elemen terpenting dalam politik seperti kemaslahatan, keadilan, shürā, persamaan (equality), kebebasan, dan kesejahteraan masyarakat, ${ }^{13}$ kendati tidak tersurat dalam teks-teks baku. Dengan pengertian di atas, terlihat bagaimana Islam sangat toleran dan moderat di dalam memandang persoalan politik dengan menekankan aspek maquașid al-siyāsahnya. Menurut Muhammad al Șalābi, ${ }^{14}$ Sikap moderasi (al-wasațīyah) terutama di dalam persoalan politik, memiliki beberapa karakter seperti amal positif dan unggul (al-khairizah), sarat keadilan (al-'adl), semangat mempermudah dan menjdi problem solver (al-yusr wa raf al-haraj), sarat dengan hikmah, ke-antara-an (al-bainayyah), dan konsisten (al-istiqämah).

Lebih lanjut, Muḥammad al Șalābī menguraikan bahwa makna "al-khairīyah" dapat diartikan sebagai umat terbaik dan unggul yang dicirikan oleh QS. Al-Imrān : 110, sebagai umat yang konsisten dalam menyeru kebaikan dan melarang kemungkaran yang kesemuanya disertai perasaan keimanan kepada Allah. ${ }^{15}$ Ciri lain dari al-wasațiyah adalah sifat ke-antaraannya (al-baināyah) sebagai pilihan sikap yang berimbang, moderat dan adil. Tidak terjebak pada ekstrem kanan (al-ghulüw) dan ekstrem kiri (al-ifrät) yang keduanya tidak mencerminkan karakter dan nilai-nilai keislaman.

${ }^{12}$ Ibid, 9.

${ }^{13}$ Khadījah al-Nabrāwī, Mausū'ah Ușūl al-Fikr al-Siyāsī wa al-Ijtimā'ì wa al-Iqtiṣādì (Kairo: Dār al Salām, 2008), 41-129.

${ }^{14}$ Muḥammad al-Ṣalābī, Al-Wasațīyah fi al-Qur'ān al-Karìm (Kairo: Dār Ibnu al-Jawzī, 2007), 8-11, 71-80, 96-107.

${ }^{15}$ Ibid, 192. 
$76 \mid$ Pemikiran Etika Politik...

Seni politik demikian dalam istilah Cholil Bisri disebut dengan al-Siyāsah al-'Ádilah yang selaras dengan maqūṣid al-sharī ${ }^{6} a h^{16}$ dengan menjadikan agama sebagai sumber etika. Berpolitik dengan menggunakan referensi etika agama menjadi perkara yang diwajibkan dan bukan sebaliknya menggunakan baju agama untuk kepentingan politik. Dalam konteks keharusan kekuasaan yang disertai etika, politik tidak hanya seni mengelola tetapi merupakan tindakan mulia karena didasarkan pada nilai etika dan moral.

Dengan lain ungkapan, jika kelompok agama tertentu mengejar kekuasaan politik demi melempangkan jalan bagi tindakan-tindakan diskriminatif, maka agama di sini tidak ubahnya seperti kekuatan jahat yang meraih kekuasaan dengan cara memanfaatkan mekanisme demokrasi. Akan tetapi, jika kelompok agama menceburkan dirinya ke dalam dunia politik karena hendak menegakkan keadilan dan kesetaraan, maka agama bisa menjadi berkah bagi sistem demokrasi modern. ${ }^{17}$

Dalam filsafat politiknya, Ibn Khaldūn menjelaskan bahwa agama merupakan kekuatan yang melekat dengan sumber kekuasaan politik. Agama adalah dasar pembangunan negara, karena bisa menyatukan elemen dalam negara dan menjadikan negara semakin kuat untuk dapat dikalahkan. Agama juga menjamin moral kolektif, pengabdian, kebaikan dan bukan sebaliknya sumber kerusuhan, ambisi individu, dan pengingkaran terhadap hak-hak sipil. ${ }^{18}$ Nilai-nilai agama yang demikian dalam istilah sekarang lazim disebut dengan "budaya politik".

Berbeda dengan politik kemaslahatan adalah politik banal sebagai antithesis dari politik beradab yang di dalam istilah Cholil Bisri disebut dengan al-siyāsah al-zälimah. Banalitas politik ini merupakan jenis politik yang tidak memuat maqūṣid al-sharī'ah sama sekali, kalau tidak disebut sebagai politik destruktif. ${ }^{19}$ Banalitas politik inilah yang turut mengantarkan kesan politik sebagai hal yang kotor, karena dalam prosesnya dilakukan melalui cara-cara tidak senonoh dan jauh dari kara etis atau berakhlak (unreason politics) mulai dari kampanye hitam (black campaign), menyebarkan berita hoaks, fitnah, politik uang dan sebagainya. Beberapa indikasi ini semakin membenarkan tesis bahwa politik itu sama dengan "siapa dapat apa, kapan dan bagaimana" (who gets what, when and how) sebagaimana corak politik Lasswellian.

Proses yang tidak senonoh di atas juga semakin menguatkan kultur politik machiavellis yang membatasi diri pada pertanyaan tentang teknik perebutan dan pertahanan kekuasaan oleh seorang raja. Hal itu dilakukannya dengan sinisme dan ekstrim. Bagi Machiavelli, politik dan moral merupakan dua bidang yang sama sekali tidak ada sangkut pautnya. Menurutnya, dalam urusan politik, perhatian terhadap norma-norma moral tidak pada tempatnya karena yang diperhitungkan adalah sukses di dalam berkuasa. Machiavelli hanya mengenal satu kaidah etika politik yakni yang baik adalah apa saja yang memperkuat

${ }^{16}$ Cholil Bisri, Al-Durr, 7-8.

${ }^{17}$ Ahmad Zainul Hamdi, "Separasi Agama-Negara dan Mitos Modernitas” dalam Kompas, edisi 12 September 2018, 7. Atau lihat, https://kompas.id/baca/opini/2018/09/12/separasi-agama-negara-dan-mitosmodernitas/. Di akses pada 14 oktober 2018.

${ }^{18}$ Abdul Rahmān Ibn Khaldūn, Al-Muqadimah (Beirūt: Dār al-Fikr, t.t.), 124-125.

${ }^{19}$ Cholil Bisri, Al-Durr, 8. 
kekuasaan raja. Segala apa yang melayani tujuan itu harus dibenarkan. Baginya, tidak ada manfaatnya ketika mempersoalkan legitimasi moral kekuasaan karena yang menentukan ialah teknik untuk merebut dan untuk mempertahankannya. ${ }^{20}$

\section{Politik Egalitarian}

Konsekuensi dari politik kemaslahatan di atas adalah terealisasinya tujuan maqūṣid al-shari'ah yang salah satu indikasinya adalah lahirnya kebijakan dan sistem politik yang egaliter. Shari’ah, sebagai sumber moral telah mengajarkan bagaimana seorang yang beriman memposisikan dirinya sebagai hamba dan pada saat bersamaan dapat memberikan kedamaian terhadap orang atau masyarakat lain. ${ }^{21}$ Secara makro, semua agama selalu mengajarkan nilainilai kebaikan kepada umatnya. Hal itu melahirkan sikap saling menghormati dan toleran terhadap sesama manusia yang memiliki komitmen menjaga keutuhan bangsa. Dalam konteks kebangsaan, bagaimana satu golongan tidak merasa superior terhadap golongan lain yang berpotensi memecah belah persatuan.

Pesan ini memiliki relevansi penting di tengah-tengah kondisi bangsa Indonesia saat ini yang dihadapkan pada model-model berpolitik yang cukup jauh dari substansi politik warga negara ideal. Model-model berpolitik yang mengedepankan sentimen kelompok dengan menghujat, menghukum serta mempersekusi kelompok politik yang berbeda dan berlawanan meski dengan cara membajak dalil agama sekalipun. Pilihan kata dan kalimat atas kelompok lainnya dengan berbagai macam sebutan yang tidak pantas dilontarkan seperti kampret, cebong turut memanaskan disparitas pilihan politik. ${ }^{22}$ Realitas politik demikian (penyematan cebong dan kampret) semakin menunjukkan perkembangan demokrasi di Indonesia masih pada tahap antagonistik dan belum sampai pada tahap deliberatif dan karenanya jauh dari nalar sehat sebagaimana yang berkembang belakangan.

Egalitarian sebagai asas kehidupan demokrasi juga menegasikan politik kekerasan yang lazimnya dilakukan penguasa sebagai bagian dari hegemoni. Politik kekerasan juga dapat dilakukan sebagian elit dalam dinamika politik nasional sebagai akibat dari perbedaan cara pandang dan kepentingan. Politik jenis ini, baik dilakukan oleh rezim terhadap rakyatnya demi menciptakan kepatuhan ataupun dilakukan oleh masyarakat terhadap pemimpinnya, tidak dapat dibenarkan. Di samping bertentangan dengan prinsip demokrasi yang menjamin kebebasan ekspresi politik dari bayang-bayang ancaman, politik kekerasan yang melekat dalam struktur politik juga akan menciderai capaian dan hasil dari proses demokrasi tersebut. Bahkan daya rusaknya butuh waktu yang lama untuk dilupakan terlebih diperbaiki. Sejarah mencatat bahwa bangsa ini memiliki jejak kelam yang larut dalam kekerasan politik mulai dari tragedi 1965, 1984 (peristiwa Tanjung Priok), 1998 (kerusuhan Mei) dan sebagainya.

Indonesia, sebagai negara yang menganut demokrasi pancasila sebagimana menjadi komitmen bersama menghendaki lahirnya persaudaraan dan ini merupakan kunci untuk

\footnotetext{
${ }^{20}$ Franz Magnis Suseno, Kuasa dan Moral (Jakarta: PT Gramedia, 1986), 8-9.

${ }^{21}$ Cholil Bisri, Al-Durr, 11.

${ }^{22}$ Zuly Qodir, “Banalitas Politik Kewargaan” dalam Kompas edisi 6 September 2018.
} 
$78 \mid$ Pemikiran Etika Politik ...

mencapai perdamaian. Kelima pasal yang tertuang dalam diktum Pancasila mencerminkan nilai-nilai Islam yang menjunjung tinggi kebebasan, persamaan dan tradisi musyawarah. ${ }^{23}$

Pesan egalitarian dalam berpolitik didasarkan pada QS. An-Nisā : 135 dan QS. AlMāidah : 8, yang menerangkan wajibnya menegakkan kebenaran dengan berlaku egaliter. Cholil Bisri membedakan istilah al-qist dengan al-'adl meskipun kedua kata ini lazim diartikan sama-sama adil. Al-qist adalah gambaran yang seimbang antara memberi dan menuntut, antara menyatakan dan menerima, sementara $a l$-'adl menunjuk pada pengertian menempatkan sesuatu pada tempatnya. ${ }^{24}$ Kedua ayat ini menegaskan bahwa Islam merupakan agama kemanusiaan dilihat dari dua hal. Pertama, Sikap egaliter hanya dapat lahir hanya dari hati yang bersih dan hati yang takwa. Sebagai esensi ibadah dan sharì ah, orang yang bertakwa adalah orang yang paling mulia yang lahir bukan dari status sosial maupun warna kulit. Kedua, tuntutan berlaku adil bersifat mutlak, baik terhadap orang yang disenangi terlebih kepada orang yang dibenci. Dari dua pesan ini menunjukkan bahwa visi Islam adalah rahmatan li al-'älamin.

Namun untuk meralisasikan visi keadilan di atas, dibutuhkan etika dan langkah prosedural untuk menunjukkan bahwa politik yang sarat dengan maqūșid al-sharī ah merupakan bagian dari ibadah dan memiliki nilai transendental. Salah satu dari etika tersebut adalah hendaknya dalam berpolitik harus disertai visi kesalihan yang akan turut menentukan kualitas kerja politik dan dengan demikian, kerja-kerja politik yang dilakukannya sarat dengan ibadah. Untuk menunjang langkah pertama ini, dibutuhkan juga program-program yang realistis dan terukur pada saat menjalankan roda politik. ${ }^{25}$ Kedua usaha tersebut dimaksudkan untuk merealisasikan visi politik egalitarian.

\section{Etika dan Reformasi Partai Politik}

Kontribusi lain Cholil Bisri terkait etika politik adalah gagasannya mengenai reformasi partai politik yang akhir-akhir ini semakin menemukan relevansi dan momentumnya. Sebagaimana maklum bahwa partai politik merupakan salah satu pilar penting demokrasi perwakilan selain lembaga eksekutif, legislatif, yudikatif, kebebasan pers, pemilihan umum dan masyarakat sipil. Bahkan pada amandemen konstitusi ketiga pada 2001, partai politik ditempatkan sebagai satu-satunya institusi yang memiliki fungsi dan tanggung jawab perekutan pejabat publik melalui pemilu, baik pemilihan legislatif maupun pemilihan presiden. Begitu pentingnya eksistensi partai, Cholil Bisri mengurai tentang kepartaian dalam satu pasal tersendiri dan dilengkapi dengan gagasan reformasi kepartaian pada pasal Etika Politik Berkeadilan.

Optimisme besar terhadap peran partai politik sangat beralasan karena secara historis, partai politik berperan penting dalam mencari dan akhirnya "menemukan" identitas keindonesiaan termasuk memperjuangkan fondasi keberagaman bagi Indonesia merdeka.

${ }^{23}$ Uraian Cholil Bishri tentang urgensi dan hubungan antara Islam dengan demokrasi dibahas pada bab politik dan Demokrasi. Selanjutnya lihat. Cholil Bisri, Al-Durr, 17-21.

${ }^{24}$ Cholil Bisri, Al-Durr, 40-41.

${ }^{25}$ Cholil Bisri, Al-Durr, 42. 
Para tokoh pergerakan, mulai dari HOS Cokroaminoto, Soekarno, Hatta, hingga Sjahrir dan M Natsir, tidak hanya membesarkan partai, tetapi juga menjadikan partai politik sebagai lokomotif perjuangan menuju Indonesia yang lebih adil. Peran penting dan strategis ini berlangsung hingga akhir 1950-an sebelum partai-partai dikuburkan oleh Soekarno di bawah Demokrasi Terpimpin (1959-1965) dan Soeharto selama 32 tahun sebagai rezim otoriter Orde Baru (1966-1998). ${ }^{26}$

Namun optimisme besar tersebut tidak selalu berbanding lurus khususnya dengan realitas politik demokrasi hari ini. Alih-alih tumbangnya Orde Baru menjadi momentum reinkarnasi partai politik yang dapat membawa maslahat, sampai pada dua dekade pasca reformasi ini, partai politik terkesan tidak pernah melakukan reformasi politik. Justru yang muncul citra buruk seperti kasus suap dan korupsi serta tingkah elit partai yang buruk. Lembaga Ilmu Pengetahuan Indonesia (LIPI) misalnya, merilis survei Pemetaan Kondisi Politik, Ekonomi, Sosial Budaya, Pertahanan dan Keamanan menjelang Pemilu Serentak 2019. Dalam penelitian yang digelar pada April-Juli 2018 itu, para peneliti menemukan bahwa DPR dan partai politik (parpol) mendapatkan persepsi terburuk sebagai instansi demokrasi. ${ }^{27}$ Sehingga, alih-alih menjadi solusi, partai politik kerap kali justru menjadi bagian dari kendala demokrasi.

Kepala Pusat Penelitian Politik LIPI Firman Noor, melihat DPR dan parpol tidak berjalan dengan baik fungsinya di masyarakat. Minimnya kaderasasi dan buruknya sistem di parpol-lah yang disebut menjadi akar buruknya kinerja DPR. Firman menilai bahwa partai politik saat ini terlihat tak mampu berperan sebagai salah satu sarana pendidikan politik bagi publik. Partai politik justru lebih mengambil jalan instan dalam setiap pemilihan agar menang. ${ }^{28}$

Untuk menghindari kebobrokan lebih jauh, menjadi relevan menyimak gagasan reformasi partai politik yang ditulis oleh Cholil Bisri, empat tahun sebelum era Orde Baru tumbang. Dari 14 poin gagasan reformasi partai politik yang ditawarkan, secara garis besar dapat diklasifikasikan sebagai berikut :

a) Partai politik harus memiliki visi kesalehan yang diwujudkan dalam bentuk arah paradigma dan ideologi yang jelas. Pada perkembangannya, prinsip ini akan mempermudah kerja-kerja politik. ${ }^{29}$ Kejelasan paradigma dan ideologi juga berfungsi untuk mengantisipasi pendangkalan makna politik yang dikesankan sekedar merebut dan mempertahankan kekuasaan belaka. Akibatnya, ideologi selalu absen dari esensi kehidupan partai politik ataupun kalau ada ideologi, tidak lebih dari performa atau lips service.

\footnotetext{
${ }^{26}$ Syamsuddin Haris, "Keniscayaan Reformasi Parpol” dalam Kompas edisi 14 September 2018.

27 https://www.gatra.com/rubrik/nasional/partai-politik/336573-Survei-Ahli-2018-Kinerja-ParpolPaling-Buruk. Diakses pada 15 Oktober 2018.

28 https:/www.cnnindonesia.com/nasional/20180808001644-32-320404/survei-lipi-dpr-parpoljadi-lembaga-bercitra-negatif. Diakses pada 15 Oktober 2018.

${ }^{29}$ Cholil Bisri, Al-Durr, 42.
} 
b) Keharusan partai politik memiliki platform yang dapat menampung dan menyatukan gagasan untuk tujuan dan kepentingan bersama. ${ }^{30}$ Wadah ini memiliki peran strategis di dalam membuat sitem dan kode etik yang dapat menjadi acuan anggota partai. Dengan standar etik yang dilembagakan, setidaknya untuk meminimalisir istilah "kutu loncat atau lompat pagar" yang lazim dilakukan para politisi.

c) Partai politik harus menjadi wadah aspirasi publik yang peka terhadap kebutuhan masyarakat. ${ }^{31}$ Dengan demikian, partai politik tidak terjebak pada pola dan sistem transaksional atau bahkan menjadi basis perburuan rente ketimbang memperjuangkan kebijakan publik. Untuk menunjukkan kontribusinya, partai politik perlu hadir setiap saat sebagai sarana pendidikan politik, bukan hanya saat menjelang pemilu.

d) Partai politik harus memiliki kemandirian ekonomi di dalam melaksanakan kerja-kerja partai. Seorang politikus yang baik tidak akan menjadikan partai politik sebagai sumber penghidupannya, justru harus menjadikannya sebagai sumber kebaikan dan kemaslahatan. ${ }^{32}$ Partai politik yang tidak memiliki kemandirian ekonomi atau sumber dana yang memadai akan berakibat pada sistem tata kelola keuangan yang abai terhadap akuntabilitas atau sistem akuntansi yang transparan. Bahkan ketergantungan pada suplai dana "haram" dari kader di eksekutif dan legislatif menjadikan likuiditas keuangan sebagian partai politik hanya diketahui segelintir pemodal partai yang berpusat pada ketua umum dan atau pemiliki partai. ${ }^{33}$

e) Keharusan adanya ketua dan atau pimpinan partai politik yang dapat membawa gerbong anggotanya kepada satu tujuan. ${ }^{34}$ Seorang pimpinan partai dapat dipilih karena memiliki karakteristik seperti kharismatik, memiliki akhlak baik, dapat diterima kehadirannya, ulet, memahami persoalan partai dan mampu menyelesaikannya.

\section{E. Penutup}

Gagasan Cholil Bisri seputar etika politik menemukan relevansinya ketika dinamika politik di Indonesia akhir-akhir ini menunjukkan pergeseran makna politik menjadi reduktif. Sebagai seorang politikus dan sosiolog yang memiliki latar belakang keulamaan kuat, gagasan politiknya terpatri dalam kerangka kemaslahatan sebagai esensi tujuan politik (maqäșid alsiyāsah). Kemaslahatan pada jenis politik ini merupakan spektrum terpenting dalam politik yang dipacu oleh cinta dan kemanusiaan. Berbeda dengan politik kemaslahatan, adalah politik banal (al-siyāsah al-zālimah) sebagai antitesis dari politik yang beradab. Banalitas politik ini merupakan jenis politik yang tidak memuat maqūșid al-sharí ${ }^{-} a h$ bahkan menjadi politik destruktif yakni politik yang abai terhadap nilai dan moralitas bangsa.

Cholil Bisri juga menyebut seni politik kemaslahatan dengan istilah al-siyāsah al'ädilah yang selaras dengan maqūșid al-sharī'ah dengan menjadikan agama sebagai sumber

\footnotetext{
${ }^{30}$ Cholil Bisri, Al-Durr, 43-44.

${ }^{31}$ Cholil Bisri, Al-Durr, 45.

${ }^{32}$ Cholil Bisri, Al-Durr, 29.

${ }^{33}$ Haris, "Keniscayaan", Ibid.

${ }^{34}$ Cholil Bisri, Al-Durr, 43.
} 
etika. Prinsip demikian berbeda maknanya dengan menjadikan agama untuk kepentingan politik. Dalam konteks keharusan kekuasaan yang disertai etika, politik tidak hanya seni mengelola tetapi merupakan tindakan mulia karena didasarkan pada nilai etika dan moral. Konsekuensi dari politik kemaslahatan ini adalah terealisasinya tujuan maqūṣid al-sharī ${ }^{\prime} a h$ yang salah satu indikasinya adalah lahirnya kebijakan dan sistem politik yang egaliter.

Kontribusi Cholil Bisri yang lain terkait etika politik adalah gagasannya mengenai reformasi partai politik seperti keharusan partai politik memiliki arah paradigma yang jelas, keharusan partai politik menjadi wadah aspirasi publik yang peka terhadap kebutuhan masyarakat dan memiliki platform partai yang dapat menampung serta menyatukan gagasan untuk tujuan dan kepentingan bersama. Gagasan reformasi partai politik lainnya adalah keharusan partai politik memiliki kemandirian ekonomi di dalam melaksanakan kerja-kerja partai yang berakibat pada sistem tata kelola keuangan yang akuntabel atau sistem akuntansi yang transparan.

\section{Daftar Pustaka}

Aziz, Munawir, "KH Bisri Musthofa: Singa Podium Pejuang Kemerdekaan”, NU Online. Diakses pada 22 Agustus 2018.

Bisri , Muhammad Khalill, t.t., Al-Durr Al-Rumbānī, Jawa Tengah: MKW dan DKW PPP. Haris, Syamsuddin, "Keniscayaan Reformasi Parpol" dalam Kompas edisi 14 September 2018.

Hendropriyono, 2009, Terorisme Fundamentalisme Kristen, Yahudi, Islam, Jakarta: Kompas. Huda, Akhmad Zainul, 2005, Mutiara dari Pesantren: Perjalanan Khidmah KH. Bisri Musthofa, Yogyakarta: LKIS.

Irfan, Agus, 2018, "Quo Vadis UU Ormas Dalam Dinamika Gerakan Islam Indonesia”, dalam Annual Conference for Muslim Scholars, ed. M. Nuril Huda, et al. Surabaya: Kopertais Wilayah IV.

--_-_-----, 2019, "Nalar Etika Politik A. Mustofa Bisri”. Disertasi-UIN Sunan Ampel Surabaya, Surabaya,

Khaldūn, Abdul Rahmān Ibn, t.t., Al-Muqadimah, Beirūt: Dār al-Fikr.

Kiras, James D. 2005, “Terrorism and Globalization" dalam John Baylis \& Stave Smith (ed), The Globalizaion of World Politics: An Introduction to International Relations, New York: Oxford University Press

Nabrāwī (al), Khadījah, 2008, Mausū'ah Ușūl al-Fikr al-Siyāsī wa al-Ijtimà̄ì wa al-Iqtị̣ādî̀, Kairo: Dār al Salām.

Riyanto, E. Ermada, 2014, Berfilsafat Politik, Yogyakarta: PT Kanisius.

Șafiyyah, Fakhrī Khalīl Abū, 1982, Muhädarāt fì al-Siyāsah al-Shar ‘ìah, Madīnah: Al Mamlakah al 'Arabìyah.

Șalābi (al), Muḥammad, 2007, Al Wasațìyah fì al Qur'ān al Karìm, Kairo: Dār Ibnu al-Jauzī. Suseno, Franz Magnis, 1986, Kuasa dan Moral, Jakarta: PT Gramedia.

Williams, Paul D. (ed), 2008, Security Studies in Introduction, London: Routletge. 
$82 \mid$ Pemikiran Etika Politik...

Viotty, Paul R. and Mark V. Kauppi, 2007, International Relations and World Politics: Security, Economy, Identity, New Jersey: Pearson Education Inc.

Winarno, Budi, 2014, Dinamika Isu-Isu Global Kontemporer, Yogyakarta: CAPS.

Qodir, Zuly, "Banalitas Politik Kewargaan” dalam Kompas edisi 6 September 2018.

Sumber Media dan Online:

"Bibit Terorisme di Kampus", Tempo (28 Mei - 3 Juni 2018), 23.

https://nasional.tempo.co/read/1029476/survei-berjihad\#fw4jtXi4Ue3WHXhM.41. Di akses pada 3 Juni 2018.

http://www.nu.or.id/post/read/40566/mengenal-almarhum-kh-cholil-Bisri. Diakses pada Selasa, 21 Agustus 2018.

https:/www.gatra.com/rubrik/nasional/partai-politik/336573-Survei-Ahli-2018-KinerjaParpol-Paling-Buruk. Diakses pada 15 Oktober 2018.

https://www.cnnindonesia.com/nasional/20180808001644-32-320404/survei-lipi-dprparpol-jadi-lembaga-bercitra-negatif. Diakses pada 15 Oktober 2018.

https://seword.com/umum/mengenal-lebih-dekat-muslim-cyber-mca-r1cwbLOdf. Diakses pada 1 Juni 2018.

https://kompas.id/baca/opini/2018/09/12/separasi-agama-negara-dan-mitos-modernitas/.

Diakses pada 14 Oktober 2018. 